\author{
ARTIGO \\ CO https://doi.org/10.22481/praxisedu.v16i38.6018
}

\title{
SABERES EXPERIENCIAIS: REFLEXÕES SOBRE A PRÁTICA PEDAGÓGICA NO ENSINO DE CIÊNCIAS E BIOLOGIA
}

\author{
EXPERIENTIAL KNOWLEDGE: REFLECTIONS OVER THE PRACTICES IN \\ TEACHING SCIENCE AND BIOLOGY
}

\section{SABERES EXPERIENCIALES: REFLEXIONES SOBRE LAS PRÁCTICAS EN LA ENSEÑANZA DE CIENCIAS Y BIOLOGÍA}

\author{
Venâncio Bonfim-Silva \\ Universidade Estadual do Sudoeste da Bahia - Brasil \\ Edinaldo Medeiros Carmo \\ Universidade Estadual do Sudoeste da Bahia - Brasil
}

\begin{abstract}
Resumo: Esta investigação tem como objetivo analisar as pesquisas acadêmicas brasileiras sobre saberes experienciais relacionadas ao ensino de Ciências e Biologia, apresentadas sob a forma de teses e dissertações, entre os anos de 2005 e 2012. O estudo é de natureza qualitativa e o corpus de análise foi composto por trinta produções acadêmicas, 27 dissertações e três teses. Para a análise das informações presentes nesses documentos, empregamos a técnica de Análise de Conteúdo Temática. Os resultados desta pesquisa apontam para a versatilidade dos saberes experienciais e suas diferentes formas de manifestação. Além disso, verificamos que o saber experiencial, por ser um saber prático e sobre a prática, contribui para o "ser professor" e auxilia, de diversos modos, na execução da prática pedagógica.
\end{abstract}

Palavras chave: Ensino de Ciências e Biologia. Formação de professores. Saberes experienciais.

Abstract: This investigation has as goal to analyze the Brazilian academic research about experiential knowledge related to Sciences and Biology teaching, presented in the form of theses and dissertations between the years of 2005 and 2012. The study is of qualitative nature and the analysis corpus was composed by thirty academic productions, of which twenty-seven dissertations and three theses. For the present information analysis in these documents, we applied the Thematic Content Analysis. The results of this research leads to the versatility of the experiential knowledge and its different forms of manifestation. Besides that, we verified that the experiential knowledge, for being a practical knowledge about the practice, contributes to "being a teacher" and helps in various ways on the execution of the pedagogical practice.

Keywords: Biology and Sciences teaching. Experiential knowledge. Teachers training.

Resumen: Ese estudio tiene como objetivo analizar las investigaciones académicas brasileñas sobre saberes experienciales relacionados a la enseñanza de Ciencias y Biología, presentadas en forma de tesis y disertaciones entre los años de 2005 y 2012. El estudio es de naturaleza cualitativa y el corpus de análisis fue compuesto por treinta producciones académicas, siendo veintisiete disertaciones y tres tesis. 
Para el análisis de las informaciones presentes en esos documentos, empleamos la técnica de Análisis de Contenido Temático. Los resultados de esta investigación apuntan a la versatilidad de los saberes experienciales y sus diferentes formas de manifestaciones. Además, verificamos que el saber experiencial, por ser un saber práctico e sobre la práctica, contribuye al "ser profesor" y auxilia de diversos modos en la ejecución de la práctica pedagógica.

Palabras clave: Enseñanza de Ciencias y Biología. Formación de professores. Saberes experienciales.

\section{Introdução}

Os saberes dos professores estão associados ao conhecimento que eles adquiriram na universidade, à sua história de vida, às experiências escolares e às vivências da profissão. Além de os professores lidarem com a mobilização dos próprios saberes, eles necessitam lidar com os saberes dos seus alunos. Assim, os saberes dos professores relacionam-se diretamente com a prática que desenvolvem. Nesse sentido, prática docente pode ser entendida numa dimensão social, a qual é dirigida por objetivos, finalidades e conhecimentos que possibilitem a execução da atividade docente (SCHMIDT; RIBAS; CARVALHO, 2003).

Segundo Tardif (2014, p. 18), o saber dos professores pode ser considerado como “[...] plural, compósito, heterogêneo, porque envolve, no próprio exercício do trabalho, conhecimentos e um saber-fazer bastante diverso, proveniente de fontes variadas e, provavelmente, de natureza diferente". Nesse sentido, para entendermos a condição plural do saber docente, devemos considerar que é oriundo da transmissão, no processo de formação saber "pré-moldado", podemos assim dizer. Para justificar este argumento, chamamos a atenção para os saberes disciplinares, curriculares e da formação profissional que, segundo Tardif (2014), são produzidos fora do contexto da sala de aula.

No que se refere aos saberes disciplinares, podemos descrevê-los como um corpo de conhecimentos específicos, que são transmitidos na universidade. Já os curriculares, são aqueles que dão conta dos métodos e objetivos de ensino, bem como dos programas e conteúdos que serão utilizados em uma determinada instituição de ensino. Por fim, os saberes da formação profissional constituem os conhecimentos didático-pedagógicos e das teorias da educação, os quais são transmitidos aos professores, ao longo da formação inicial ou continuada.

Desse contexto de formação profissional, percebemos que a universidade e a formação que é dada por ela formam o elo entre os saberes previamente sistematizados para formar professores e os futuros docentes, os quais terão como locus de trabalho os espaços formais e 
não formais de ensino ${ }^{1}$. Assim como Tardif (2014, p. 40), compreendemos os saberes referidos anteriormente como sendo "mais ou menos de segunda mão", uma vez que eles não são produzidos pelos próprios professores. O que se pode verificar é que, no percurso de formação, os iniciantes na profissão, por um lado, relacionam-se com esses saberes, transmitindo conhecimentos disciplinares de acordo com os livros didáticos, ou aqueles que foram elaborados por programas educacionais adotados pela instituição de ensino em que atuam. Por outro, mesmo sem compreender em sua totalidade a relação de saberes que influenciam a prática social que exercem, fazem escolhas teórico-metodológicas baseadas, muitas vezes, nos saberes da formação profissional que receberam na universidade.

Quando refletimos sobre a situação citada anteriormente, o resultado é a subordinação dos docentes aos "saberes de segunda mão". Isso se reflete, de modo bastante negativo, no ensino, uma vez que um dos protagonistas desse processo, o professor, é considerado como mero transmissor ou executor de conhecimentos sistematizados e externos à sua prática, ao invés de ser percebido como produtor de saberes durante sua prática pedagógica. Desse modo, o saber que fundamenta a prática do professor não pode ser constituído unicamente pelos saberes disciplinares, curriculares e da formação profissional. Por isso, faz-se necessário uma investigação mais atenta da prática docente e dos saberes produzidos pelos professores, isto é, os saberes experienciais, para que eles venham a ser mais protagonistas do que coadjuvantes em sua profissão.

É nessa óptica que Tardif (2014), Nunes (2001), Santos (2014), Therrien (1997), Gauthier et al. (2013) e Shulman (1986; 1987) procuraram compreender, de maneira aprofundada, a relação dos professores com os seus próprios saberes.

Nessa perspectiva, considera-se que o saber docente vai sendo transformado por meio da prática pedagógica e se integra à identidade dos docentes ${ }^{2}$ no decorrer das suas vivências cotidianas, constituindo-se como um "saber original” (NUNES, 2001, p. 31) dos próprios professores. Assim, o professor desenvolve a sua formação mediante a autoformação e reelaboração de saberes iniciais, no exercício de sua profissão.

\footnotetext{
${ }^{1}$ Entendemos que o espaço formal de ensino é a escola, incluindo todas as suas dependências, ou até mesmo as instituições de Ensino Superior. Isto é, locais onde a educação formalizada, e garantida por lei, acontece. Por outro lado, os espaços não formais de ensino referem-se às instituições que não têm como objetivo a educação formal, a exemplo dos museus e dos zoológicos, e também aos lugares não institucionalizados, como praças, rios, dentre outros (JACOBUCCI, 2008).

${ }^{2}$ A identidade docente, segundo Pimenta (2005), além de se construir a partir do valor social que a profissão tem, constrói-se pelo significado que cada professor dá a ela, baseado em seu ofício, em seus valores, em suas crenças, em suas representações, em sua história de vida, em suas angústias e seus anseios, e nas relações estabelecidas com seus pares, seus alunos, sua escola, e em outros espaços e agrupamentos.
} 
Assim, os saberes que são mobilizados pelos professores terão como resultado um novo saber, o saber experiencial, o qual possui uma relação direta com o contexto de sala de aula e com as atividades cotidianas do docente. Conforme destaca Tardif (2014, p. 48-49), o saber experiencial é constituído por um “[...] conjunto de saberes atualizados, adquiridos e necessários no âmbito da prática da profissão docente e que não provêm das instituições de formação nem dos currículos".

Em consonância com essa visão, entendemos que os saberes experienciais são também fruto da ação reflexiva do professor sobre sua própria prática. Não se pode considerar estritamente que os professores "de carreira" possuem mais saberes experienciais do que aqueles que acabaram de entrar na profissão, tendo em vista que o "saber-ser" e o "saber-fazer" são próprios de cada sujeito e fruto tanto da sua formação acadêmica quanto da sua história de vida. Entretanto, os saberes práticos ou experienciais são produzidos somente a partir da reflexão desse sujeito sobre seu próprio "saber-ser" e "saber-fazer", a fim de consolidar a sua prática cotidiana naquilo que o constitui, isto é, na sua identidade enquanto professor.

De acordo com as reflexões de Santos (2014), a respeito dos saberes experienciais, compreendemos que tais saberes são construtores de uma epistemologia da prática, todavia, isso não quer dizer que sejam melhores ou piores do que os outros saberes, mas que se apoiam em uma práxis ${ }^{3}$. Em vista disso, apostamos na fertilidade da reflexão sobre a prática docente e na aquisição de saberes daí advindos, os quais são singulares e contextualizados, sendo fundamentais tanto na formação inicial como na continuada, constituindo, assim, o lugar dos saberes experienciais.

\section{Percurso metodológico}

\section{a) Organização sistemática dos dados}

O primeiro passo para a execução da pesquisa foi a escolha das fontes de dados ${ }^{4}$ para o levantamento e a obtenção das dissertações e teses. Baseando-nos no rigor metodológico

\footnotetext{
${ }^{3}$ A práxis pode ser entendida como uma prática que não tem um caráter estritamente utilitário, mas é orientada por finalidades conscientes e intencionais da ação docente, alicerçada numa teoria, que visa à transformação da prática social e à construção de um conjunto de meios para a execução da atividade profissional, sempre considerando a indissociabilidade da relação entre teoria e prática, mediante o movimento de ação e reflexão do sujeito (SCHMIDT; RIBAS; CARVALHO, 2003; AZZI, 2005; GHEDIN, 2006).

4 Considerando os documentos que podem ser utilizados como fonte de dados para uma pesquisa documental e por compreender que analisar "[...] documentos implica fazê-lo a partir do ponto de vista de quem os produziu [...]" (SILVA, et al., 2009, p. 4557), ressaltamos que nossa fonte de dados foi constituída de documentos secundários, na forma de dissertações e teses, e que estas foram analisadas considerando o ponto de vista de cada autor dessas produções acadêmicas.
} 
exigido para um trabalho do tipo Estado da Arte, bem como na legitimidade científica necessária para a seleção das produções acadêmicas, optamos pela consulta ao catálogo de teses e dissertações da Coordenação de Aperfeiçoamento de Pessoal de Nível Superior - CAPES ${ }^{5}$ e ao banco de teses e dissertações do Domínio Público ${ }^{6}$.

Após a escolha das fontes, delimitamos o corpus da pesquisa (conjunto de documentos que seriam analisados) temporal e quantitativamente. $\mathrm{O}$ ano que elegemos para determinar o início do levantamento foi 2005 - por ser este o ano mais antigo no qual encontramos um trabalho que estivesse de acordo com os objetivos da pesquisa, ou seja, analisar as pesquisas acadêmicas brasileiras sobre saberes experienciais relacionadas ao ensino de Ciências e Biologia - e o limite que estabelecemos foi o ano de $2012^{7}$. No conjunto, foram identificadas 30 produções acadêmicas, sendo 27 dissertações e três teses. Ressaltamos que, em razão dos objetivos do presente estudo, do conjunto de produções identificadas, apenas 11 foram selecionados para análise. Para facilitar a citação e organização dos documentos, estabelecemos um critério de identificação: cada produção acadêmica recebeu um código composto pela primeira letra do nível de pós-graduação seguida de um algarismo (ex.: “D. 01”, para a dissertação no 1 e "T.03", para a tese n 3 ).

\section{b) Análise dos dados da pesquisa}

A investigação qualitativa do corpus da pesquisa foi realizada por meio da Análise de Conteúdo Temática, a qual consiste numa técnica interpretativa, denotativa e inferencial. A definição de Berelson (1952, apud AMADO; COSTA; CRUSOÉ, 2013, p. 302-303) para a Análise de Conteúdo (temática, em nossa pesquisa) atende ao que necessitávamos como procedimento de análise de dados, visto que "[...] consiste numa técnica de pesquisa documental que procura arrumar num conjunto de categorias de significação o conteúdo manifesto dos mais diversos tipos de comunicação [...]".

Para a construção das categorias de análise dos dados numa base temática, partimos da leitura exaustiva e cuidadosa da introdução, do capítulo metodológico, do(s) capítulo(s) de

\footnotetext{
5 Para acessar ao catálogo de teses e dissertações da CAPES ver link disponível em: <https://catalogodeteses.capes.gov.br/catalogo-teses/\#!/>. Acesso em: 05 jul. 2019.

6 Para acessar o banco de teses e dissertações do Domínio Público ver link disponível em: <http://www.dominiopublico.gov.br/pesquisa/PesquisaPeriodicoForm.jsp>. Acesso em: 05 jul. 2019.

7 O levantamento e obtenção das teses e dissertações foi realizada pelos autores no ano de 2015. Inicialmente foram identificadas 30 produções acadêmicas, sendo 17 dissertações e uma tese no banco de teses e dissertações do Domínio Público, publicadas entre os anos 2005 e 2010. Já no catálogo de teses e dissertações da CAPES foram encontradas 10 dissertações e duas teses relacionadas publicadas nos anos 2011 e 2012.
} 
resultado(s) e das considerações finais de cada documento, no intuito de delimitar as unidades de contexto e, posteriormente, as unidades de registro (BARDIN, 2011), sendo estas as matérias-primas principais que compuseram as categorias propositivas e terminais. Cada categoria construída no decorrer desta pesquisa seguiu estritamente estes critérios propostos por Bardin (2011): exclusão mútua, homogeneidade, pertinência, objetividade, fidelidade e produtividade. Tendo adotado a produção do saber experiencial como temática central da análise, conforme será explorada a seguir, foi possível chegar a duas categorias: Contribuições dos saberes experienciais para o "ser professor" e Saberes experienciais: elo articulador dos saberes docentes.

\section{Contribuições dos saberes experienciais para o "ser professor"}

A reflexão a respeito dos saberes experienciais leva-nos a considerar alguns aspectos que lhes são bastante específicos. Assim, é válido discutir a maneira pela qual esses saberes são expressos pelos professores, sua configuração no contexto da prática pedagógica e o modo como eles se desenvolvem ao longo da carreira docente. Nessa perspectiva, discorreremos, neste artigo, sobre essas e outras características dos saberes experienciais, fazendo uso dos dados analisados.

Conforme já discutido, de acordo com Tardif (2014), os saberes experienciais não são provenientes das instituições de formação de professores nem dos currículos, mas são adquiridos, atualizados, tornando-se essenciais na prática diária de cada docente. Desse modo, identificamos aqui duas distinções deste tipo de saberes em relação aos que chamamos de "saberes sistematizados", isto é, os saberes disciplinares, curriculares e da formação profissional. A primeira distinção refere-se à fonte de formação dos saberes experienciais, a qual não é proveniente, exclusivamente, da formação inicial dos professores, nem de programas curriculares das instituições escolares, sendo, portanto, saberes produzidos fora desses contextos. A segunda diferença refere-se ao locus de construção, mobilização e atualização desses saberes, isto é, a prática docente. Em função disso, o campo de atuação do professor ganha outro significado, passando de um espaço de aplicação para um ambiente fomentador de saberes.

No exercício da atividade docente, seja em espaços formais ou não formais de ensino, os professores colocam em prática os conhecimentos teóricos, didáticos, pedagógicos e curriculares que possuem, sendo o saber experiencial o elo que faz conexão entre esses conhecimentos para pô-los em prática. Para Tardif (2014), esse saber se manifesta por meio de 
um saber-ser e saber-fazer pessoal e profissional, os quais são validados pela execução do trabalho, ou seja, pela prática pedagógica de cada professor. Porém, conforme afirmam Carmo e Selles (2015, p. 241), “A imersão na prática [...] não potencializa, em si mesma, um aprendizado docente reflexivo e crítico. Segundo Ghedin (2006), o saber experiencial do professor é produzido historicamente, num contexto de reflexão crítica, a respeito das próprias experiências profissionais, e alicerçado na indissociabilidade entre a teoria e a prática. Desse modo, os saberes experienciais compõem um conjunto de representações que possibilita aos professores mobilizar os demais saberes, interpretar e compreender as diversas situações que ocorrem em sala de aula com o objetivo de orientar tanto sua profissão quanto sua prática.

Sobre essa vertente dos saberes experienciais, apresentamos a seguir excertos das produções analisadas que evidenciam esses fatos.

[...] decorre disso a grande importância que os professores dão aos saberes experienciais. A valorização desses saberes da experiência já foi predito por Tardif (2002) e encontra eco nas declarações de Ana [...]. Contudo, a despeito de considerar a atuação prática do professor como essencial ao seu processo de formação Ana destaca que há a necessidade de contrapor as observações práticas realizadas no exercício diário da profissão, com a teoria pedagógica. (D. 01).

Dentre os elementos observados nas análises os que mais se destacaram relacionam-se aos discursos proferidos pelos professores em suas falas, que se assemelham [...] a mobilização de saberes experienciais. A valorização dos saberes pertencentes a essa categoria é acompanhada de uma menor valorização dos saberes profissionais e disciplinares [...]. Acredita-se que estes configuram um conjunto de informações que não podem ser acessadas facilmente pelo indivíduo ficando a percepção de sua influência camuflada pela maior valorização dos saberes práticos que compõem a base dos saberes experienciais. (T.01)

Como podemos perceber no fragmento anterior, destacado na D. 01, a valorização dos saberes experienciais é um tema recorrente nas dissertações e teses que analisamos. A esse respeito, identificamos, nas produções, que os professores lançam mão desses saberes: por exemplo, quando os saberes disciplinares não são suficientes para a abordagem adequada de um conteúdo, os docentes valem-se das experiências adquiridas no decorrer da trajetória profissional e articulam os saberes experienciais aos pedagógicos e didáticos com a finalidade de suprir dadas deficiências e amenizar as dificuldades decorrentes delas. De acordo com T. 01 e D. 01, a supervalorização dos saberes da experiência se dá em virtude da insuficiência dos outros saberes ou pela relevância que os professores dão aos saberes experienciais em relação aos demais. 
Ao considerarmos os diversos aspectos que compõem e influenciam os saberes experienciais, é oportuno refletirmos sobre o modo pelo qual eles são construídos. Utilizando a analogia da sucessão ecológica, uma dissertação descreve o saber experiencial como um ambiente a ser colonizado pelos saberes disciplinares, curriculares e da formação profissional. Observemos o fragmento dela retirado:

Na busca por uma analogia desse processo de confronto com a realidade, na e
sobre a prática e ressignificação dos saberes, encontramos um exemplo ligado
às Ciências Biológicas: a sucessão ecológica. "Esse processo consiste nas
mudanças na estrutura das espécies na comunidade ao longo do tempo"
(ODUM, 1988, p. 283) [...]. Como analogia temos os saberes experienciais
fazendo o papel do ambiente físico que vai ser "colonizado" pelos saberes
disciplinares, profissionais e curriculares. No início do processo todos são
pouco complexos. Gradativamente, o contato com novos organismos gera
condições, ou seja, modificam os saberes experienciais, e permitem que
saberes disciplinares, profissionais e curriculares mais complexos
transformem novamente a base de saberes experienciais. Como toda analogia
é, por definição, limitada (CACHAPUZ, 1989), esta também tem seus limites.
Diferentemente do processo de sucessão ecológica, não se espera que esta
atinja um estágio clímax. Ao contrário, o processo tende a continuar
indefinidamente enquanto existirem novas "espécies" (saberes) para colonizar
e transformar o ambiente físico (base de saberes). (D. 01).

Dessa analogia, depreendemos que a construção do saber experiencial se dá paulatinamente e ao longo do tempo. Assim, refletimos que, em um primeiro momento, tem-se um saber pouco complexo, sem muitas interações com os outros tipos de saber. Contudo, a partir da realidade cotidiana de trabalho, o professor começa a produzir o saber experiencial em sua prática pedagógica, pois, a mobilização dos demais saberes e dos outros fatores que têm relação direta com o ensino, a exemplo da gestão da matéria e gestão da classe (GAUTHIER, et al., 2013), tornam o saber experiencial cada vez mais complexo. Embora, na analogia de sucessão ecológica, tenha-se o "clímax" como estágio final, esse mesmo processo não ocorre com os saberes experienciais, visto que, a cada aula, o docente faz uso desses saberes conferindo-lhes um nível de complexidade (ou heterogeneidade) cada vez maior, fato que é bastante positivo tanto para o professor quanto para o ensino.

Nessa perspectiva, encontramos indícios, nas dissertações e teses que analisamos, de que os saberes experienciais possuem certa versatilidade e amplo poder de interatividade, sendo assim, passíveis de renovação, reconfiguração e aperfeiçoamento. Esses processos, na maioria das vezes, ocorrem por meio da reflexão dos professores em duas circunstâncias: a primeira refere-se à reflexão sobre a prática pedagógica durante a ação ou depois dela; a segunda está associada ao contato dos professores com os seus pares. 
Para exemplificarmos a primeira circunstância, trazemos um aspecto bastante apontado pelas produções, que vem a ser a confrontação com a prática. Nesse sentido, ilustramos, genericamente, essa situação de confrontação com aquilo que é usual no cotidiano da profissão docente. No momento em que o professor se depara com os desafios impostos cotidianamente no exercício de sua profissão, os saberes experienciais são postos em prática e daí decorrem os processos reflexivos do professor sobre a sua prática pedagógica, com vistas a resolver uma determinada problemática. Caso isso ocorra no momento da ação, o desafio torna-se ainda maior, tendo em vista a necessidade imediata de tomada de atitude por parte do docente. Entretanto, independente do momento em que ocorra a reflexão crítica sobre a prática, o saber experiencial é utilizado e, certamente, ele estará sendo aprimorado, assim como a prática do professor. A seguir, expomos excertos das produções acadêmicas que ilustram esse cenário.

Esse confronto adiciona, a cada dia, novos elementos aos saberes experienciais. Presume-se que nesse processo de confronto e de busca e reflexão, ocorre um processo de ressignificação dos saberes e conhecimentos adquiridos durante o curso da carreira profissional. (D. 01).

As entrevistas com os docentes, buscando conhecer o perfil deles, fez-me compreender que a aproximação com a docência deu-se por vários caminhos [...]. É comum o elemento "saber da experiência" para reflexão da renovação da prática docente. (D.18).

No que se refere à influência dos saberes experienciais na reflexão sobre a prática, nos contextos de interação dos docentes com seus pares (o diálogo com colegas, as reuniões de professores, os momentos de atividades complementares ou os grupos de estudos), verificamos que, quando o professor está em contato com seus pares, esse contato funciona como uma espécie de "força motriz" dos saberes experienciais. Acreditamos que isso ocorra, principalmente, em virtude de os professores exporem opiniões a respeito da própria profissão, da prática pedagógica, do conteúdo que foi ou será trabalhado e estarem, também, expostos, nesses momentos, a opiniões que divergem das suas. Ou seja, na interação com seus pares, os professores mobilizam e produzem saberes experienciais. Nessa interação ocorre contínuo processo de reflexão, tanto no sentido de reforçar a prática quanto em reconfigurá-la. Esses diversos fatores podem ser observados nos trechos que seguem.

Para os sujeitos desta pesquisa uma das lembranças atribuída foi a relação com os pares, ou seja, os colegas de profissão. Na tentativa de reconstrução desses momentos, os protagonistas deste estudo relembram: [...] a relação com os pares é muito significativa, no sentido de superar as dificuldades, é um ajudando outro, mostrando onde é que está o erro, as falhas às vezes na gente, 
às vezes no sistema ou na clientela (Professora Dália, Entrevista, 2009). [...] Fica evidente nestes relatos que os professores consideram a relação, ou seja, a socialização com os colegas de profissão como um dos fatores marcantes para aquisição/mobilização do saber experiencial. A Professora Dália diz que, às vezes, se encontra saturada, no sentido de se sentir incapaz de lidar com as situações inconstantes da sala de aula, e encontra nos colegas formas de lidar com essas situações. (D. 17).

Outro ponto que merece destaque em nosso estudo diz respeito àquelas pesquisas que empregaram uma metodologia participativa, a exemplo das dissertações D. 19, D. 24 e D. 27. Esse caráter próximo entre pesquisadores e sujeitos das pesquisas, no próprio ambiente escolar, sugere que essa relação é bastante propícia para a construção e mobilização de vários saberes, como afirmam Mota, Prato e Pina.

[...] a potencialidade e vitalidade da produção dos saberes docentes e do próprio desenvolvimento profissional dos professores, nos parece residir exatamente no conjunto de práticas reflexivas e investigativas que podem ser constituídas nas escolas, seja pelos profissionais que lá atuam, seja num trabalho de parceria e colaboração com outros agentes, como por exemplo, estudantes e pesquisadores da universidade. [...] nestas situações de reflexão, investigação e colaboração acerca do próprio trabalho, os professores fazem uso de uma multiplicidade de saberes, mudando de atitude diante do conhecimento, tomando-os como verdades provisórias que acionados, postos em movimento num dado contexto, rompem-se com análises simplificadoras e aplicacionistas, o que fertiliza uma postura investigativa, fazendo reflexões sobre o que se descobre. (2008, p. 131).

Nas produções analisadas, a mobilização e a construção dos saberes experienciais foram as mais citadas, sendo, por sua vez, evidenciados, em decorrência de terem sido reconfigurados e aperfeiçoados através do contato entre sujeitos e pesquisador(a). A título de exemplo, identificamos esse processo nas produções que demonstraram uma interação próxima entre esses indivíduos, tais como em pesquisas realizadas em grupos de estudo, com construção de sequências didáticas (ou unidades didáticas), em processos de formação continuada e naquelas que fizeram dos cursos de graduação o seu campo de investigação, conforme apresentamos nos trechos a seguir.

Pelo exposto, podemos compreender que o papel do professor é mais complexo do que simplesmente transmitir conhecimento já produzido (PEREIRA, 2000). O professor em exercício vai construindo conhecimento sobre o ensino, ao mesmo tempo em que partilha com os licenciandos o resultado de suas elaborações e dos saberes experienciais construídos ao longo do exercício da profissão. (D. 24). 
Seu saber experiencial teve relação direta com a sua formação continuada e ela (a professora) nos deu indícios disso nas respostas das questões que perguntavam sobre a sua participação no projeto e o seu trabalho como professora, e no que tinha em mente quando trabalhava com os alunos [...]. A sua vivência, sua formação continuada, provavelmente permitiu que a professora mobilizasse saberes diversos, e que testasse essa recombinação de assuntos. E essa mescla trouxe-lhe um saber próprio, ou seja, o saber experiencial, com a particularidade de que, posteriormente, esta experiência foi levada novamente ao grupo de estudos, para ser discutido e analisado. [...] Já a professora de Biologia, ao colocar em prática a Unidade Didática [UD] planejada e produzida em grupo, concomitantemente desenvolveu seus saberes experienciais. [...] Os estudos que aconteciam, em grupo, as reuniões para discussões de textos, entre outras atividades das quais a professora participava, foram processos de mobilização de saberes experienciais. [...] E no contexto do projeto, esse saber experiencial pôde ser compartilhado, coletivizado. Suas experiências, angústias, descobertas e constatações foram socializadas, com a finalidade de uma readequação e reaplicação desta UD. (D. 19).

Em relação ao trabalho colaborativo também devemos destacar que todo o contexto, o curso Redefor, as entrevistas, as reuniões do Grupo de Diálogos e Estudos, propiciaram o intercâmbio de saberes (disciplinares, experienciais, pessoais, curriculares, etc.) entre os professores e pesquisadores. [...] Observase, nesse processo de mudança, a influência de diversos fatores e saberes. Inicialmente, no processo de formação continuada, ocorreu o contato com as discussões referentes às concepções históricas errôneas sobre Lamarck. Em seguida, uma análise reflexiva e o conflito entre as concepções da Professora PB com o texto de Martins (1998). Por fim, essa desestruturação nos conhecimentos da Professora PB, juntamente com seus saberes experienciais e a intervenção do pesquisador, iniciaram uma mudança em sua prática docente. (D. 27)

Semelhante ao processo de mobilização dos saberes experienciais que citamos anteriormente, identificamos a utilização do desses saberes durante a ação, isto é, no momento em que a aula ocorre. Trazemos um fragmento de uma dissertação, em que o sujeito da pesquisa faz uso desse saber para a gestão da classe, no intuito de reverter um episódio de dispersão dos alunos durante uma aula de Botânica. É evidenciado pela autora de D. 07 que a expressividade do saber experiencial ocorre, não apenas para a gestão da classe, mas em articulação com uma série de outros fatores, levando-nos a entender a complexidade e, ao mesmo tempo, o dinamismo, que envolve esse tipo de saber. Em seguida, apresentamos o excerto de D. 07, exemplificando esses fatos.

O controle da turma diminui, e nesse instante o P1 faz uma pergunta à turma [...]: "o que seriam algas?", provocando a atenção de todos, com a intenção que volte o envolvimento inicial, consegue com esta atitude a resposta de um aluno, pondo em construção um diálogo bilateral. Nesse momento percebe-se o uso de uma estratégia do professor em função da gestão da classe, fazendo 
uso nesse momento do diálogo, resultando na interação. O P1 segue explicando o assunto usando tons de vozes, ora mais alto, ora mais baixo e gesticulando, para atingir a atenção, o envolvimento e a aprendizagem dos alunos. Aqui nessa ação do P1, revela uma articulação de saberes [...] estratégicos e os saberes da experiência [...]. Neste momento as preocupações do professor estariam relacionadas não apenas à gestão da sala, mas, ao processo cognitivo, à organização social da classe, à concentração na tarefa que estava realizando e, por fim, com o gerenciamento das explicações para atingir a compreensão e a aquisição do conceito abordado, atingindo, dessa forma, o maior número de alunos, já que sabemos que a aprendizagem se realiza de maneira diferente para cada aluno. [...]. Nas ações acima realizadas pelo $\mathrm{P} 1$, estão presentes a gestão da classe, da matéria e do conteúdo, portanto o saber da experiência em ação. (D. 07).

Neste fragmento, percebemos, claramente, a mobilização dos saberes experienciais para fomentar a aprendizagem dos alunos a respeito do conteúdo que estava sendo abordado. Para isso, a autora de D.07 enfatiza que o professor fez uso de uma "estratégia" para conseguir um maior envolvimento da turma, ou seja, assumiu atitudes pedagógicas que permitiram o gerenciamento tanto da matéria quanto da classe. No excerto, identificamos tanto o uso dos saberes experienciais quanto dos "modos de fazer" (CARMO; SELLES, 2013) para que a gestão da classe fosse eficiente. Com respeito aos "modos de fazer", Carmo e Selles (2013, p. 2253) enfatizam que eles podem ser percebidos em “[...] produções tipicamente escolares que se produzem de modo dinâmico ao longo da prática docente [...]". Neste caso, os "modos de fazer" do professor apresentavam forte ligação com a gestão da classe e da matéria (GAUTHIER et al., 2013).

Em outras produções, temos a demonstração do uso dos saberes experienciais na reflexão sobre prática docente, com o objetivo de aperfeiçoamento profissional. No excerto a seguir, quando o participante da pesquisa realiza uma autoavaliação, ele recorre ao seu saber experiencial para identificar, por exemplo, os erros e acertos cometidos e, também, traçar estratégias para aperfeiçoar sua prática.

[...] como força motriz da renovação de sua atuação docente o saber da experiência, tanto como aluna, quanto como docente, demonstrando momentos de reflexão de sua prática, mesmo que depois da ação: "Eu acho que a gente vai aprendendo à medida que o tempo vai passando, né, não fazendo aquilo que você achava que os seus professores faziam [...]. Por que lá na Agronomia eu passei por isso: excelentes professores, mas eles não conseguiam passar para a gente, eles não tinham facilidade. Algumas coisas que eu sei que eu ainda tenho que melhorar também e eu mesmo me avalio de um semestre para o outro, aquilo que eu achei que... Quando eu olho, eu achei que poderia ter sido melhor e posso não ter sido eu já tento não cometer os mesmos erros, né, porque eu acho que independente do tempo que você tem 
de trabalho a tendência é você querer produzir melhor e não estagnar, né, então a gente vai aprendendo à medida que o tempo vai passando". (D. 18).

Verificamos que os saberes experienciais exercem uma influência significativa no processo de reflexão dos professores sobre sua prática. Por meio desse processo, o professor renova suas ações pedagógicas e produz saberes próprios, pois eles, os docentes, não são agentes passivos na construção e mobilização dos saberes. Concordamos com Tardif (2014) ao afirmar que os docentes são "sujeitos ativos" e sua prática não é somente um espaço de aplicação, mas também de produção de saberes específicos.

\section{Saberes experienciais: elo articulador dos saberes docentes}

Numa óptica um pouco diferente da que temos tratado até aqui, mas que ainda possui certa ligação com os processos reflexivos realizados pelos professores, verificamos, nas dissertações e teses analisadas, que os saberes experienciais desempenham o papel de articular os demais saberes. Desse modo, “[o]s saberes profissionais, curriculares e disciplinares, são [...] a base sobre a qual age a reflexão, estimulada pelas múltiplas realidades e experiências vividas pelo professor, o que resulta na composição dos saberes experienciais” (D. 01). Outro ponto, que ficou bastante evidente em nossa pesquisa, foi o fato de que a preparação teórica dos professores, antes das aulas, assim como a busca por novos conhecimentos, reforça o saber experiencial que possuem, tornando-se um auxílio fundamental à sua prática docente. Nos fragmentos subsequentes, observamos alguns desses aspectos.

Talvez a maior importância dos saberes da experiência demonstrados pela professora 1 resida no fato de que eles podem funcionar como um "filtro" dos outros saberes, possibilitando uma re-visão e uma re-avaliação dos saberes adquiridos anteriormente e exteriormente à prática profissional propriamente dita. E, sendo assim, podem promover a emergência e consolidação de um "novo saber, um saber formado de todos os saberes retraduzidos e submetidos ao processo de validação constituído pela prática cotidiana" (TARDIF, 1991, p. 231). (T. 01).

Essa insatisfação pode, de certo modo, ser o catalisador de um processo de busca por novos conhecimentos, indicando que um processo de reflexão sobre a prática ocorre a partir do conflito entre a realidade encontrada na atuação profissional e os conhecimentos e saberes recebidos durante a formação inicial. E, provavelmente, decorra disso a grande importância que os professores dão aos saberes experienciais. (D. 01).

Nestes termos, a carência de uma formação para o professor do ensino superior, provoca no mesmo a mobilização de saberes da experiência para 
solucionar situações conflituosas no processo de ensino e aprendizagem do dia a dia, promovendo um novo modo de ações, comportamentos profissionais e determinando condutas próprias de reorganização de conceitos em uma práxis diferenciada, fundada em teorias reelaboradas que produzem novos saberes. (D. 13).

Entendemos que a atualização e busca por novos conhecimentos são fundamentais para que os docentes aprimorem o seu trabalho, adquiram maior embasamento teórico e fortaleçam suas experiências. Por conseguinte, acreditamos que os professores se tornam mais capazes para observar a realidade, problematizá-la, propor soluções e intervir de modo assertivo nas situações que lhe são apresentadas no cotidiano do seu trabalho, sendo concebido, assim, um novo olhar sobre o ensino, tal como sobre seu papel na formação de cidadãos críticos e reflexivos. Isto posto, concordamos com a autora de T. 01, quando ela se refere aos saberes experienciais como uma espécie de "filtro" para os demais saberes.

Entendemos também que é no exercício da prática que os professores desenvolvem "modos de fazer" (CARMO; SELLES, 2013) específicos de trabalharem com os objetos de ensino, ou seja, desenvolvem ações concretas para a mobilização de um determinado tipo de saber. No excerto a seguir, vemos uma demonstração desses "modos de fazer" no relato da Professora PB, quando fala de como estava planejando executar a sua aula.

[...] vou começar com o vídeo que mostra desde a célula até o DNA, [...] porque esse vídeo é muito significativo: porque o aluno, muitas vezes, nem sabe onde o DNA está no organismo. Eu acho que isso vai despertar o interesse neles, porque, quando o assunto envolve o corpo deles, isso faz com que eles perguntem. Depois vamos trabalhar com os bloquinhos de montar a estrutura do DNA, que vai dar pra aproveitar pra trabalhar a parte de duplicação e transcrição e, no final, fazemos o experimento de extração do DNA. (D. 27).

Um fato que nos chama a atenção no excerto anterior é que a professora se apoia nos saberes experienciais que adquiriu ao longo da carreira para trabalhar com os saberes disciplinares relacionados a Citologia e a Biologia Molecular. Nesse exemplo, percebemos que o saber experiencial é personalizado, sendo adquirido por cada docente ao longo de sua história pessoal e profissional. Conforme argumenta Tardif:

[...] o saber dos professores é o saber deles e está relacionado com a pessoa e a identidade deles, com a sua experiência de vida e a sua história profissional, com as suas relações com os alunos em sala de aula e com os outros atores escolares na escola, etc. (TARDIF, 2014, p. 11, grifos do autor). 
Vemos assim que é na prática, isto é, na execução de seu fazer pedagógico, que o professor manifesta este saber. "O sentido do saber fazer e do saber ser, a experiência do professor é parte do que ocorre num dado momento vivido, algo que ele possa ter. Como disse certo professor entrevistado: 'Eu não tenho uma experiência, eu vivencio, eu experiencio"” (D. 09). E, acrescenta o autor, "Posso inferir neste caso que a experiência docente é a ação conjunta de tudo o que o docente vivencia em determinados momentos, é a história, é tudo que projeta como também é o momento presente que vive" (D. 09).

A esse respeito, acreditamos que o saber experiencial está relacionado a um saber que é imerso e legitimado pela prática e se integra a tudo o que diz respeito a ela. Para nós, esses saberes são exclusivos de cada sujeito, porque são mobilizados por eles no dia a dia de sua profissão, no intuito de melhor responderem às demandas que aparecem na sala de aula, tais como: modos de trabalhar com os conteúdos; meios particulares de solucionar problemas em sala ou de conduzir a turma; maneiras pessoais de ter a atenção dos alunos durante as aulas e facilitar a aprendizagem deles; enfim, a apropriação de diferentes "modos de fazer", como afirmam Carmo e Selles (2013), que facilitam o exercício de sua profissão. Para elucidar alguns desses aspectos, trazemos estes trechos extraídos das produções analisadas.

$\mathrm{Na}$ fala da professora se observa seus saberes da experiência, aqueles adquiridos na prática docente, atualizados e reatualizados e que não provém das instituições de formação nem do currículo. (T. 01).

De uma forma geral, os professores não apresentam conhecimentos sobre teorias de aprendizagem como fundamentação para as suas práticas docentes. $\mathrm{Na}$ maioria deles ficou preponderante o saber experiencial, decorridos de erros e acertos durante sua trajetória profissional, ou do uso de modelos referenciais - seus professores a quem buscava aproximar-se ou não. (D.18).

Como alternativas para superação da insegurança e despreparo apontados pelas entrevistadas para ensinar Ciências nos anos iniciais do ensino fundamental, a maioria destaca [...] o aprendizado que ocorre com a profissão, no próprio exercício da docência ou na troca de experiências com outros professores. Nesse sentido, mesmo se tratando de uma pesquisa com professores em formação inicial, são indicados elementos relacionados aos saberes experienciais, que são aqueles que os professores desenvolvem com base em seu trabalho cotidiano e são baseados em suas experiências. (D. 10).

Diante disso, percebemos a estreita ligação que possuem os saberes docentes com o ambiente de trabalho do professor e com os outros aspectos que se associam ao contexto escolar, a exemplo das reuniões de área, da interação entre os pares, e entre professores e alunos. Assim, compartilhamos com Tardif $(2014$, p. 21) a ideia de que "[...] ensinar é mobilizar uma ampla 
variedade de saberes, reutilizando-os no trabalho para adaptá-los e transformá-los pelo e para o trabalho", sendo essa reutilização impraticável sem os movimentos reflexivos do professor em relação aos seus saberes e ao contexto educacional no qual ele está inserido.

\section{Considerações finais}

Durante a análise, foi possível perceber várias nuances dos saberes experienciais, desde a sua produção e aperfeiçoamento até a sua influência na mobilização dos demais saberes. Além disso, verificamos que o saber experiencial, por ser um saber prático e sobre a prática, auxilia o professor de diversos modos na execução do seu trabalho. Observamos também a versatilidade dos saberes experienciais e suas diferentes formas de manifestações. Contudo, todos esses elementos aqui relatados sobre os saberes experienciais têm relação direta com sua temporalidade.

A ideia de temporalidade é a de que, ao longo do tempo, o professor vai aprendendo o ofício de ensinar, conforme reitera Tardif (2014), sendo essa aprendizagem marcada pela sua história de vida e pela construção do saber profissional, que engloba as vivências acadêmicas e profissionais. Nesse sentido, acreditamos que por meio do saber experiencial, adquirido no exercício de sua prática, o professor pode se tornar capaz de refletir sobre as diversas influências que estão latentes em seu ambiente de trabalho. Assim, por meio de suas ações e decisões, o docente aprimora a si mesmo, do ponto de vista pessoal e profissional e, consequentemente, sua prática pedagógica.

Reconhecemos que os saberes experienciais estão em constante movimento e são dotados de uma dinâmica que lhes é particular. Misturando-se com a subjetividade de cada indivíduo, estes saberes configuram a prática pedagógica dos professores, que é atravessada por influências pessoais, sociais e coletivas, e está inserida numa realidade histórica. Logo, entendemos que, se o professor exerce sua profissão de modo reflexivo, o tempo contribuirá significativamente para o "ser professor" por meio do desenvolvimento, da reconfiguração e do aperfeiçoamento de seu saber experiencial.

\section{Referências das dissertações e teses consultadas}

BRAGA, André. Os saberes de professores que ensinam Ciências nas séries iniciais: um estudo de caso. 146 f. Dissertação (Mestrado em Educação). Universidade Federal de São 
Carlos, São Paulo, São Carlos, 2005. Orientadora: Profa. Dra. Cármen Lúcia Brancaglion Passos. [D. 01].

ANDRADE, Maria da Conceição Moreno de. Saberes disciplinares e experiências articuladas em aulas de Biologia. $101 \mathrm{f}$. Dissertação (Mestrado em Ensino de Ciências). Universidade Federal Rural de Pernambuco, Pernambuco, Recife, 2007. Orientadora: Profa. Dra. Rosane Maria Alencar da Silva. [D. 07].

MELO, Luiz Arlindo Ramos de. A prática pedagógica e a construção de saberes do biólogo no ensino de Física em Ciências na $8^{a}$ série. 112 f. Dissertação (Mestrado em Educação em Ciências e Matemática). Universidade Federal do Pará, Pará, Belém, 2007. Orientadora: Profa. Dra. Maria de Fátima Vilhena da Silva. [D. 09].

RODRIGUES, Maria de Lourdes Bandeira. A prática pedagógica dos professores de Ciências Naturais de $5^{\mathrm{a}}$ a $8^{\mathrm{a}}$ série do ensino fundamental: discutindo os saberes docentes. 191 f. Dissertação (Mestrado em Educação). Universidade Federal do Piauí, Piauí, Terezinha, 2007. Orientador: José Augusto de Carvalho Mendes Sobrinho. [D. 10].

MASINI, Elís Regina. Saberes docentes do Ensino Superior: desvelando saberes analisando o contexto. 93 f. Dissertação (Mestrado em Educação para a Ciência e o Ensino de Matemática). Universidade Estadual de Maringá, Paraná, Maringá, 2009. Orientadora: Ana Lúcia Olivo Rosas Moreira. [D. 13].

SOARES, Antonina Mendes Feitosa. Ação docente em Ciências Naturais: discutindo a mobilização dos saberes experienciais. 227 f. Dissertação (Mestrado em Educação). Universidade Federal do Piauí, Piauí, Teresina, 2010. Orientador: José Augusto de Carvalho Mendes Sobrinho. [D. 17].

CARDOSO, Nilson de Souza. Como ensinam os professores de Ciências Biológicas? Um estudo sobre a relação pesquisa e ensino na prática docente. 109 f. Dissertação (Mestrado em Educação). Universidade Estadual do Ceará, Ceará, Fortaleza, 2011. Orientadora: Isabel Maria Sabino de Farias. [D. 18].

FINCO-MAIDAME, Gabriela. Saberes docentes na interface Biologia/Geociências: contribuições de uma professora em formação continuada. 163 f. Dissertação (Mestrado em Ensino e História de Ciências da Terra). Universidade Estadual de Campinas, São Paulo, Campinas, 2011. Orientador: Henrique César da Silva. [D. 19].

PAREDES, Giuliana Gionna Olivi. Um estudo sobre o PIBID: saberes em construção na formação de professores de ciências. 171 f. Dissertação (Mestrado em Educação em Ciências e em Matemática). Universidade Federal do Paraná, Paraná, Curitiba, 2012. Orientador: Orliney M. Guimarães. [D. 24].

TAKAHASHI, Bruno Tadashi. Trabalho colaborativo entre universidade e escola: proporcionando a formação continuada através da história da Biologia. 100 f. Dissertação (Mestrado em Educação para a Ciência). Universidade Estadual Paulista "Julio de Mesquita Filho”, São Paulo, Bauru, 2012. Orientador: Fernando Bastos. [D. 27]. 
OLIVEIRA, Rosemary Rodrigues de. O ensino de Ciências nas séries iniciais do ensino fundamental: compreendendo discursos de professoras-alunas do curso pedagogia-cidadã. 150 f. Tese (Doutorado em Ensino de Ciências). Universidade Estadual Paulista "Julio de Mesquita Filho”, São Paulo, Bauru, 2007. Orientador: Renato Eugênio da Silva Diniz. [T. 01].

\section{REFERÊNCIAS}

AMADO, João; COSTA, António Pedro; CRUSOÉ, Nilma. A técnica de Análise de Conteúdo. In: AMADO, João. (Coord.). Manual de Investigação Qualitativa em Educação. 2. ed. Coimbra: Imprensa da Universidade de Coimbra, 2013, p. 301-351.

AZZI, Sandra. Trabalho docente: autonomia didática e construção do saber pedagógico. In: PIMENTA, Selma Garrido. (Org). Saberes pedagógicos e atividade docente. 4 ed. São Paulo: Cortez Editora, 2005, p.35-60.

BARDIN, Laurence. Análise de conteúdo. 6. ed. Lisboa: Ed. 70, 2011, 223p.

CARMO, Edinaldo Medeiros; SELLES, Sandra Escovedo. As práticas como objeto de análise dos saberes docentes e a produção do conhecimento escolar: combinando 'modos de fazer' no ensino de Biologia. In: Congreso Internacional sobre investigación en didáctica de las Ciencias, 9., 2013, Girona, Comunicación... Girona, 2013, p. 2251-2254. Disponível em: <https://www.raco.cat/index.php/Ensenanza/article/view/307821/397800 >. Acesso em: 25 de Mai. 2019.

Experiências formativas na escola e visões de docência de licenciandos de Ciências Biológicas. Práxis Educacional, Vitória da Conquista: Ediuesb, v.11, n. 19, p. 231-246, 2015. Disponível em: 〈http://periodicos.uesb.br/index.php/praxis/article/view/4771>. Acesso em: 26 jul. 2019.

GAUTHIER, Clermont. et al. Por uma teoria da pedagogia: pesquisas contemporâneas sobre o saber docente. 3. ed. Ijuí: Unijuí, 2013, 480p.

GHEDIN, Evandro. Professor reflexivo: da alienação da técnica à autonomia da crítica. In: PIMENTA, Selma Garrido; GHEDIN, Evandro (Org.). Professor reflexivo no Brasil: gênese e crítica de um conceito. 4. ed. São Paulo: Cortez, 2006, p. 129-150.

JACOBUCCI, Daniela Franco Carvalho. Contribuições dos espaços não-formais de educação para a formação da cultura científica. Em Extensão, Uberlândia, v.7, p.55- 66, 2008.

Disponível em:

<http://www.seer.ufu.br/index.php/revextensao/article/download/20390/10860 >. Acesso em 24 mai. 2019.

MOTA, Ednacelí Abreu Damasceno; PRADO, Guilherme do Val Toledo; PINA, Tamara Abrão. Buscando possíveis sentidos de saber e conhecimento na docência. Cadernos de Educação, n.30, p. 109-134, jan./jun. 2008. Disponível em: 
$<$ https://periodicos.ufpel.edu.br/ojs2/index.php/caduc/article/view/1761/1639>. Acesso em 10 jan. 2017.

NUNES, Célia Maria Fernandes. Saberes docentes e formação de professores: um breve panorama da pesquisa brasileira. Educação e Sociedade, ano 22, n.74, p. 27-42, abr. 2001. Disponível em: 〈http://www.scielo.br/pdf/es/v22n74/a03v2274.pdf>. Acesso em: 28 ago. 2015.

SANTOS, José Jackson Reis dos. Sobre saberes construídos com base nas práticas pedagógicas: reflexões introdutórias. In: RAMALHO, Betania Leite; CRUSOÉ, Nilma; NUNES, Claudio Pinto (Org.). Formação para docência profissional: saberes e práticas pedagógicas. 1. ed. Brasília: Liber Livro, 2014, p.87-100.

SCHMIDT, Leide Mara; RIBAS, Mariná Holzmann; CARVALHO, Marlene Araújo de. A prática pedagógica como fonte de conhecimento. In: ALONSO, Myrtes (Org.). O trabalho docente: teoria e prática. 2. ed. São Paulo: Pioneira Thomson Learning, 2003, p. 19-36.

PIMENTA, Selma Garrido. Formação de professores: identidade e saberes da docência. In: PIMENTA, Selma Garrido. (Org). Saberes pedagógicos e atividade docente. 4. ed. São Paulo: Cortez Editora, 2005, p.15-34.

SHULMAN, Lee. Those who understand: the knowledge growths in teaching. Educational Reseacher, v.15, n.2, p.4-14, fev. 1986. Disponível em: <https://pdfs.semanticscholar.org/f29d/a5d8c806102b060e7669f67b5f9a55d8f7c4.pdf>. Acesso em: 15 abr. 2015.

Knowledge and teaching: foundation of a new Reform. Harvard Educational Review, v.57, n.1, p.1-23, abr. 1987. Disponível em: <https://people.ucsc.edu/ ktellez/shulman.pdf>. Acesso em: 15 abr. 2015.

SILVA, Lidiane Rodrigues Campêlo da. et al. Pesquisa documental: alternativa investigativa na formação docente. In: IX CONGRESSO NACIONAL DE EDUCAÇÃO - IX EDUCERE - III ENCONTRO SUL BRASILEIRO DE PSICOPEDAGOGIA - III ESBP, 2009, Curitiba. Anais do IX EDUCERE - III ESBP. Curitiba: Champagnat, 2009, p. 4554-4566.

Disponível em: 〈https://educere.bruc.com.br/arquivo/pdf2009/3124_1712.pdf〉. Acesso em: 10. jan. 2017.

TARDIF, Maurice. Saberes docentes e formação profissional. 17. ed. Petrópolis, RJ: Vozes, 2014. 325p.

THERRIEN, Jacques. Saber da experiência, identidade e competência profissional: como os docentes produzem sua profissão. Contexto e Educação, v.12, n.48, p.7-36, 1997. Disponível em:

<http://jacquestherrien.com.br/wp-content/uploads/2014/06/Saber-da-Experi\%C3\%AAnciaComo-os-Docentes-Produzem-sua-Profiss.pdf>. Acesso em: 20 ago. 2016. 


\section{SOBRE OS AUTORES:}

\section{Venâncio Bonfim-Silva}

Mestrado em Educação, Universidade Estadual do Sudoeste da Bahia (UESB); Secretaria Estadual de Educação do Estado da Bahia - Brasil; Programa de Pós-Graduação em Educação; Grupo de Pesquisa Currículo e Formação Docente. E-mail: venasbonfim@gmail.com

(iD http://orcid.org/0000-0003-4033-8244

\section{Edinaldo Medeiros Carmo}

Doutor em Educação, Universidade Federal Fluminense (UFF); Universidade Estadual do Sudoeste da Bahia (UESB) - Brasil; Programa de Pós-Graduação em Educação; Grupo de Pesquisa Currículo e Formação Docente. E-mail: medeirosed@uesb.edu.br

iD http://orcid.org/0000-0002-1594-8983

Recebido em: 14 de agosto de 2019 Aprovado em: 01 de outubro de 2019 Publicado em: 01 de janeiro de 2020 